\title{
Compensations For Death - Change In Approach Is Needed In Bangladesh
}

\author{
MIRA SAJJAN \\ Lecturer, Department of Law and Justice, Southeast University, Dhaka, Bangladesh
}

\begin{abstract}
For personal injury claims, civil courts usually offer handsome amount of compensations but when death occurs, the dependants of the deceased get a nominal amount or even sometimes they get nothing. This situation of deprivation is common more or less in different countries of the world. This article indicates a comparative study among three countries and suggests some constructive and positive changes for Bangladesh in case of accidental death claims. British Common Law has gone through several transforms in this arena of tort law and still it requires more modifications. Whereas, in India, this field is becoming popular as the courts are addressing these claims with remarkable judgments. However, the legal position of Bangladesh is disappointing. The attitude of courts regarding several recent incidents of death has raised frustration.

The objective of this study is to identify and analyze the legal problems and solutions faced by the other countries and presenting a clear path for Bangladesh civil courts to provide better tortious protections towards the dependants of the person died in accidents.
\end{abstract}

Keywords- Tortious claims, Common Law, unliquidated damages, solatium, fatal accidents

\section{INTRODUCTION}

The whole area of the civil law stands upon an ancient legal maxim of Ubi jus ibi remedium, which means, 'where there is a right, there is a remedy'. Whenever the court is convinced that there is an unjustifiable interference with the rights of a person, it is the duty of the court to provide a remedy for the same. When such unlawful interference arises against a person's lawful right and when there is no breach of contract, breach of trust or other equitable obligations (Salmond \& Heuston, 1992), rather than a breach of legal duty, the obligation of the law of tort arises. Law of tort is also referred as 'civil wrong' and it is a separate branch of civil law. Law of tort attracts a common law action for unliquidated damages rather than punishment. Damages are unliquidated because they are not usually pre-determined and pre-prescribed by any codified provisions of the law. Therefore, just like England, in Bangladesh, this area of law is dependent on the concept of justice, equity and good conscience of the Judges. Case references direct that a huge amount of tortious compensations can be obtained from the personal injury claims but death, being the higher end of seriousness, is yet struggling to be identified as a justly compensated area. The object of the article is to point out and compare the legal developments, effects, and payable compensations for death as a tortious liability in different countries.

\section{DEATH AND ITS EFFECT OVER THE PERSONAL CAUSE OF ACTION IN COMMON LAW}

The maxim "actio personalis moritur cum persona", suggests that a personal cause of action dies with the person. English Common Law also follows this general rule and maintains that the death of either party extinguishes any existing cause of action in tort by one against the other. However, this rule has two exceptional situations firstly, in actions under contract and secondly, the unjust enrichment of tortfeasor's estate (Bangia, 2012) or in other words, where property had been wrongly appropriated by the deceased person and added to his own estate (Rogers, 2010).However, this rule has been abrogated by the passing of the Law Reform (Miscellaneous Provisions) Act, 1934 (Bangia, 2012). This Act provides that "on the death of any person....all causes of action subsisting against or vested in him shall survive against or as the case may be for the benefit of his state." ${ }^{\text {Th }}$ Thus, presently the general rule is that if a cause of action comes into existence in the lifetime of the parties, the death of either the plaintiff or the defendant does not affect the cause of action. It means that a subsisting cause of action survives despite of the fact that either of the parties to the action dies. For example, if a person is injured in an accident, he may suffer loss in the form of medical expenses, loss of income during or after confinement because of being incapacitated from doing his normal work, pain and suffering or the reduction in the expectation of his life. He can obviously bring an action for the same. Supposing the injured man, either before bringing an action, or before an action brought by him is finally decided, dies, the legal

${ }^{1}$ Law Reform (Miscellaneous Provisions) Act, 1934 Section 1 (1) 
representatives of the deceased are entitled to pursue the same action. It may be mentioned that the basis of the action which the legal representatives are entitled to bring under the Law reform Act 1934 is to claim compensation for such loss which had occurred to the deceased in his lifetime but he could not claim compensation for the same due to his death (Bangia, 2012).

\section{PRESENT POSITION IN ENGLAND}

Presently in England, personal injuries claims boast at 99 per cent settlement rate, which is unusually high for any area of contested litigation (Hedley, 2011). For personal injury claims, when the loss is itemized and proved $^{2}$ that it was suffered by the plaintiff in consequence of the defendant's tort, gets special damages. In addition to that, plaintiff gets general damages, which fall under this five heads of pain and suffering, loss of the amenities of life, loss of future earnings, loss of earning capacity, future expenses.

However, the death of the plaintiff is only rarely a ground for increasing damages, and frequently a ground for reducing them (Hedley, 2011). Only the dependant relatives ${ }^{3}$ of the deceased can demand at least part of the income stream they would have received had the death not occurred (Rogers, 2010).

\subsection{The Rule in Baker v. Bolton}

It was decided in a case of Baker v Bolton ${ }^{4}$ that an action for smaller injuries lies in civil law, however, "in civil court, the death of human being could not be complained of as an injury." Thus, this principle is known as the rule in Baker $v$ Bolton.

In this case, the plaintiff and his wife were travelling in a coach. The coach gone upset by the negligence of the defendants and that caused a severe accident. The plaintiff himself suffered bruise and his wife was so severely hurt, that she died about a month later in a hospital. The plaintiff could recover compensation for his injury and the loss of his wife's distress, from the death of the accident to the date of her death only. He could not recover anything of such loss after death.

\subsection{Exceptions of the rule}

\subsubsection{Death Caused by the breach of contract}

Negligently causing the death of a person is not actionable, but if the death is the result of a breach of a contract, the fact of death may be taken into account on determining the amount of damages payable on the breach of a contract. In a case $\mathrm{s}^{5}$ the plaintiff purchased a tin of salmon from the defendant and the plaintiff's wife died by eating some salmon from that tin. It was held that, the plaintiff was entitled to claim compensation for the loss of services of the wife due to her death.

\subsubsection{Compensations for death under different statutes} examples are:

In England, there are various statutes for compensating the instance of death of a person. Some of the

a. The Coal-Mining (Subsidence) Act, 1957

b. $\quad$ The Carriage by Air Act, 1967

c. The Carriage by Railway Act, 1972

d. The Carriage of Passengers by Road Act, 1974

e. The Merchant Shipping Act, 1979

f. The Fatal Accidents Act, 1976

These above-mentioned Acts are not related with the tort claims therefore, they do not carry much importance for this article. However, Fatal Accidents Act, 1976 contains an important exception to the rule in Baker v Bolton (Bangia, 2012).

\subsubsection{The Fatal Accidents Act , 1976}

Until 1840, English Civil Courts reluctantly followed the Rule in Baker v Bolton and rarely paid compensations for death. Due to enormous increase in the number of injuries and deaths, it became something of a public scandal that the injured railway passengers could sue, but dead ones could not (Hedley, 2011). The need for compensating the dependants, led to the enactment of Fatal Accidents Act, 1846, also known as Lord Campbell's Act. The main claim today remains the same as introduced in 1846, though it has been restated and

\footnotetext{
${ }^{2}$ In this two cases, the Court of Appeal laid down that precise itemization of each award was mendatory: Jefferson $v$ Gee (1970) 2 QB 130 (CA) \& George v Pinnock (1973) 1 WLR 118 (CA).

${ }^{3}$ List of dependants is provided in Fatal Accidents Act, 1976 (c 30).

${ }^{4}$ (1808) 1 Camp. 493: 10 R. R. 734, 735

${ }^{5}$ Jackson $v$ Watson (1909) 2 K.B. 139

DOI: 10.9790/0837-2109104248 
slightly expanded since then (Hedley, 2011). The list of dependants contained in the Act $^{6}$ of 1846 has been considerably enlarged by the revised $\mathrm{Act}^{7}$ of 1976 and this was further amended by the Administration of Justice Act, 1982.

The dependants are listed now as:

a. The spouse, or former spouse, or a person who has been living as a spouse of the deceased in the same household for at least two years immediately before the death of the deceased;

b. $\quad$ Any parent or other ascendant of the deceased, or a person who was treated as a parent by the deceased;

c. Any child or other descendant of the deceased, or a person who was treated by the deceased as a child ${ }^{8}$ of the family, and

d. Any person who is, or is the issue of, brother, sister, uncle or aunt of the deceased.

\section{PAYABLE COMPENSATION FOR DEATH TO THE DEPENDANTS IN ENGLAND}

The compensation is payable for the pecuniary loss suffered by the dependant only and nothing can be recovered by way of Solatium for mental suffering and anguish. Where a man has no means of his own and earns nothing, his wife and children cannot be pecuniary losers and no statutory claim will be placed at their instance ${ }^{9}$. The gratuitous services rendered by wife or mother in the home are equivalent to pecuniary benefit for which damages can be claimed ${ }^{10}$.

In the case of recognizable psychiatric injury an action lies but not for the fear, horror ${ }^{11}$ or emotions because such feelings can no doubt be described as a suffering but not damages. Prospective loss has to be taken into account while assessing compensation payable for death. In a case $\mathrm{e}^{12}$, on the death of a 16 year years old girl, her parents were entitled to get compensation as the girl had all probability to earn substantial amount in the near future on completing her apprenticeship as a dressmaker, although she was not earning anything at the time of her death.

Previously, the law was that, if the widow of a deceased man remarries and her husband is a wealthier or more generous provider, then on this narrow conception the dependency would be very low ${ }^{13}$ or even nonexistent: the death has not caused the widow a significant financial loss (Hedley, 2011). Steve also continued to say that-

... a common tactic by defence counsel in the early $20^{\text {th }}$ century was to parade the more attractive claimant widows before the court, to support an argument that a future profitable re-marriage was very likely (the 'cattle market' approach, as it was known). It eventually led to a change in the law in 1971, so that presently the actual or potential remarriage of a plaintiff widow is ignored.

Non-financial loss was for the first time addressed in $1982^{14}$, when legislation allowed for the claim to include a sum for 'bereavement', nothing related to any kind of financial loss. This is currently set at $£ 10,000^{15}$. If the deceased was married, the sum belongs to the spouse; if he or she was an unmarried legitimate minor, it belongs to both his and her parents; if an unmarried illegitimate minor, then to her mother; otherwise, the sum is not claimable ${ }^{16}$. The $\mathrm{Act}^{17}$ does not apply to a stillborn child, though since the tort causing the stillbirth will be a tort against the mother, she may recover substantial damages (not necessarily limited to the statutory sum) for the effect to the loss of the child on her ${ }^{18}$.

\section{RECENT POSITION IN INDIA}

In India, there are various statutes for compensating the event of death of a person. Some of the examples are:

a. The Workmen's Compensation Act, 1923

b. The Indian Railways Act, 1890

c. The Carriage by Air Act, 1972

d. Civil Aviation Act, 1949

e. Indian Aircraft Acts, 1945

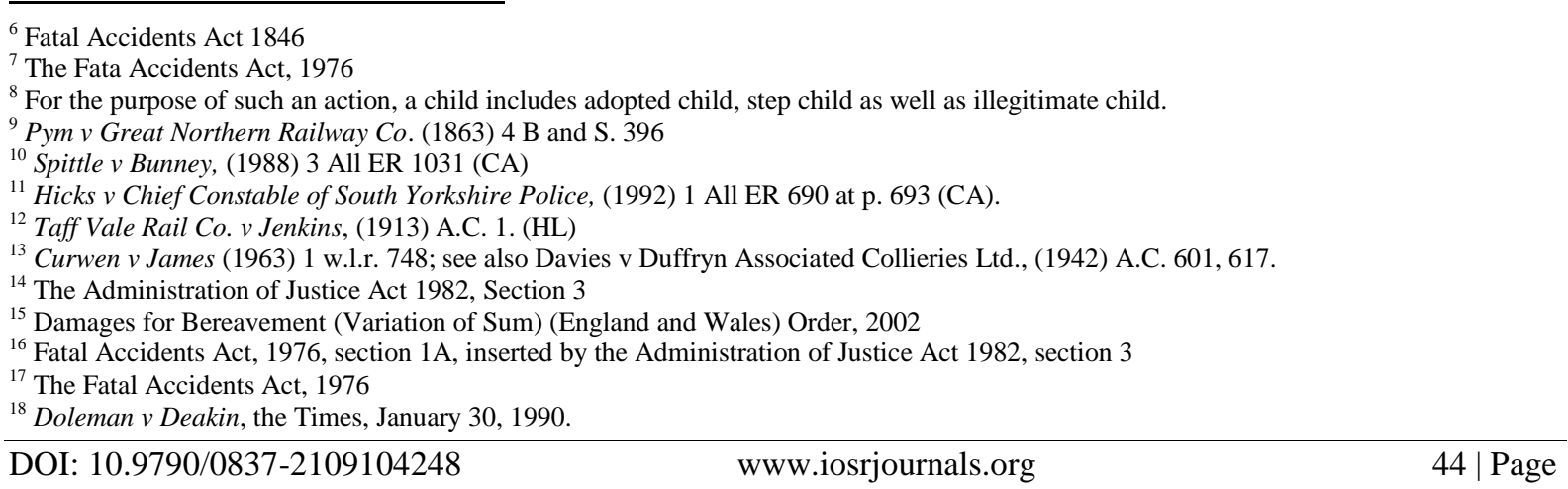


f. The Air Corporations (Amendment) Act, 1971

g. $\quad$ The Non-International Carriage (Passenger and Baggage) Regulations, 1973

h. The Fatal Accidents Act, 1855

These above mentioned acts mainly deal with liquidated compensations, which are not related with the tort claims except the Fatal Accidents Act, 1855, which has a direct bearing on the subject matter of this article. Regarding an action for compensation on the death of a person, the position in India is not much different from that in England (Bangia, 2012). The Fatal Accidents Act, 1855 recognizes certain dependants and tort actions for their benefit, on the death of a person. Section $1 \mathrm{~A}$ of this $\mathrm{Act}^{19}$ contains that the death of a person caused by wrongful act, neglect or default is actionable and every such action or suit shall be for the benefit of the wife, husband, parent and child. Under this Act, a new right of action has been conferred on the following relatives, viz., wife, husband, parent that includes father, mother, grandfather and grandmother; and child, which includes son, daughter, grandson, granddaughter, stepson and stepdaughter ( Pillai, 2004). Brothers and sisters are not legal representatives (Bangia, 2012) within the meaning of this section and therefore, no action is maintainable by the brother of the deceased ${ }^{20}$. Unlike England, joint family system is still remaining strong in India and the dependants in actual practice include brothers, sisters, uncles, aunts, and generally widows of the brothers and other near relatives, thus, there is a great need for enlarging the list of the dependants by amending the (Indian) Fatal Accidents Act (Bangia, 2012). The need for such an amendment has been emphasized by the Kerala ${ }^{21}$ and the Delhi ${ }^{22}$ High Courts.

\section{PAYABLE COMPENSATION FOR DEATH TO THE DEPENDANTS IN INDIA}

If a statute stipulates the payment of some compensation in the event of death of a person, compensation for death can be claimed on that basis. For example, in a case ${ }^{23}$, the appellant's husband died on an electric shock after he came in contact with a live electric wire. The High Court ordered payment of compensation of Rs. 60,000 based on a circular issued by the Maharashtra State Electricity Board. In an another case $^{24}$ a child aged six years had died due to falling in uncovered sewerage and Rs 50,000 with $12 \%$ interest was allowed as compensation to the father without giving any reasons.

In India, the Ministry of Road Transport and Highways (MRTH) is planning to cap the maximum limit of compensation in case of death in road accident to Rs 15 lakh. Ministry is in process to bring in Road Transport and Safety Bill (RTSB) to replace the existing Motor Vehicle Act 1988 (Babele, 2016).

Damages are allowed for pecuniary loss; they are not given as a Solatium for injured feelings (Pillai, 2004). In addition, damages for bereavement are not available in Indian statutes. However, some High Courts of different States of India have allowed compensation for mental agony and injured feelings of sons, daughters and parents of the deceased ${ }^{25}$. The Orissa High Court did not allow solatium to parents ${ }^{26}$.

\section{PRESENT SITUATION OF ACCIDENTAL CLAIMS IN} BANGLADESH

In Bangladesh, several statutory frameworks deal with the instance of wrongful death of a person. Such as:

a. The Penal Code, 1860

b. The Motor Vehicles Ordinance 1983

c. The Employers' Liability (Compulsory Insurance) Act 1969

d. $\quad$ The Road Traffic Act 1988

e. The Consumer Rights Protection Act, 2009

f. The Fatal Accidents Act, 1855

In addition, compensations can be claimed under other various statutes and regulations. The subject matter of this article relates with only two statutes above, i.e. the Consumer Rights Protection Act, 2009 and the Fatal Accidents Act, 1855. This Act of 1855 was passed before the separation of this subcontinent and no amendment was so far done in Bangladesh, like India. Therefore, the discussion, which has already been made about the Fatal Accidents Act, 1855 of India, for example, the list of dependants etc. remains the same in Bangladesh. However, this Act has no frequent use in Bangladesh, because civil actions for unliquidated

\footnotetext{
${ }^{19}$ The Fatal Accidents Act, 1855 Section 1A

${ }^{20}$ Budha $v$ Union of India, A.I.R. 1981 M.P. 151

${ }^{21}$ P.B. Kader v Thatchamma, A.I.R. 1970 Ker. 241 at 243, per Krishna Iyer J.

${ }^{22}$ Dewan Hari Chand v Delhi Municipality, A.I.R. 1981 Delhi 71, at 74, 75, per V.S. Deshpande, C.J.

${ }^{23}$ Shashikalabai $v$ State of Maharashtra (1999)A.I.R. S.C. 706

${ }^{24}$ Kumari $v$ State of Tamil Nadu (1992) AIR SC 2069

${ }^{25}$ J.R. Daniel v T. Vaithuswaran, AIR 1989 Mad 5; New India Insurance Ltd. v Sarda Devi, AIR 1989 Pat 203 at p. 209; Bhanwarlal v Harilal, AIR 1994 MP 10 at p. 13

${ }^{26}$ Kumodini Das v Baliar Singh, AIR 1996 Ori 32

DOI: $10.9790 / 0837-2109104248$

www.iosrjournals.org 45 | Page
} 
compensation or in other words, tort actions are not well recognized yet in our legal system. This is because the law of tort is not codified and the section 9 of the Code of Civil Procedure, 1908 enables a civil court to try all suits of civil nature, also confer upon courts the jurisdiction to apply the law of torts as an undeniable part of principles of justice, equity and good conscience ${ }^{27}$. Hence, without reliance on statutory provisions, pressing damages as a tort claim purely on equitable ground is quite unlikely in Bangladesh because civil courts are now surviving with a number of problems, for example, inadequacy of courts, complexity, delay, lack of training of judges etc. The Consumer Rights Protection Act, 2009, has many loopholes and it failed to meet the present need (Ali, 2011). The Act provides that any complaint concerning defective product resulting in substantial financial or physical damage must be filed within 30 days to the Department for Protection of Consumer Rights. This time limit is too short because there can be some long-term effect which would be impossible to identify immediately. ${ }^{28}$ Section 71 (1) of the Act stipulates that no individual can make any complaint about violation of consumer rights to the Magistrate. Thereby the people are placed at the mercy of the Department for Protection of Consumer Rights for enforcing the rights given to them. Such drawbacks ultimately made the act nugatory.

\section{COMPENSATIONS PAYABLE IN BANGLADESH}

In Bangladesh, most of the naval accidents happen because of the negligence of the launch and other water vehicle operators and their owners. Whenever any launch accident occurs, the government pays minimum amount as compensation to the victims in case of death. For that purpose, Bangladesh Inland Water Transport Authority (BIWTA), working under the Ministry of Shipping formed a Board (Nou-Durjog Tahobil Trustee Board) for funding the water-transport accident cases. In 2003, the Trustee Board approved that for the death of one person, the family will be compensated with 15000 taka and for the death of two or more persons of a family the compensation will be 20000 taka. Later, based on the decisions of several meetings held in 2004, 2009, 2011, 2013, 2014 and 2015 the amount of compensation has increased now in 1,50,000 taka for death in launch accidents. The Fund is collected from the launch owners union (where they deposit 10 taka for each passengers yearly) and from the terminal ( 2 taka is deposited from the terminal ticket fee). ${ }^{29}$

In road accident cases, given the silence of law, usually the owner of the vehicle comes to an agreement with the victims' family in terms of some monetary compensation. However, only a few number of tort cases has gone to the court and become successful.

The Appellate Division of the Supreme Court of Bangladesh gave a landmark decision. The order upheld the verdict of the high court division to compensate the victim's family in a case involving the death of a former news editor of the 'Daily Sangbad,' in a road accident in the year 1989. In this case, a truck owned by Bangladesh Beverage Industries Limited had run over the news editor and, thereafter, in the year 1991, the wife of the deceased filed a case before the district judges court of Dhaka under the Fatal Accident Act 1855, seeking Tk. 3.52 crore as compensation from BBIL. The lower court decided in favour of the dependant of the deceased and allowed for the compensation by the company. When the decision was put before the High Court on appeal, saying that the company could not be held liable for the driver's mistake; the High Court rejected the plea stating that the company could indeed be asked to pay compensation, and fixed the sum of compensation. Finally, the Appellate Division of the Supreme Court disposed of an appeal filed by the BBIL challenging the verdict given by the High Court Division.

In this case, the trial court considered tortuous liability on the basis of the doctrine of vicarious liability, which bases on the principle that he who does an act through another is deemed in law to have done it himself (Ahmed, 2016).However the progress is quite frustrating in other cases, in case of Jihad's death, after falling into a pipe of an abandoned deep tube well at the Shahjahanpur Railway Colony in the capital the trial has been pending with the Detective Branch (DB) of police. Shahjahanpur Thana police submitted a charge sheet to a Dhaka court four months after filing the case. But the DB police have yet to submit the investigation report of the case even after nine months. So the trial of the case has been stranded (Islam, 2016). Also no progress is observed yet in another case, of August 13, 2011, where prominent film director Tarek Masud and journalist Mishuk Munir died in a tragic road accident.

Devastating incidents like Rana Plaza collapse case, Tazreen Factory Fire case etc. could not come up with satisfactory results. A number of Dependants of deceased's and other injured workers of these incidents are still suffering without compensations and those who were paid, paid less than enough (Guguen, 2014).

\section{RECOMMENDATIONS}

Cases discussed above are attention grabbing, but there has so many other accidents, which do not even come to the courts for proper redress because majority of the people of Bangladesh are not aware about their right or not conscious about the protection of law of torts. The fear of going to the courts most of the times

\footnotetext{
${ }^{27}$ Union Carbide Corporation v Union of India (Bhopal Gas Disaster case) 1988 MPLJ 540

${ }^{28}$ Ibid

${ }^{29}$ Informations were collected by the author from the office of BIWTA. BIWTA VABAN, Dhaka-1000
}

DOI: $10.9790 / 0837-2109104248 \quad$ www.iosrjournals.org $\quad 46 \mid$ Page


stop them from seeking redress and also the instances of delay and sufferings caused by the civil courts to the parties of an action, discourage them to claim rights. Only courts and lawyers can pull this obstacle down and create positive attitude towards courts.

The law of tort has already been adopted by many countries worldwide and especially in our neighbouring countries, including Sri Lanka, Nepal and India; day by day, it is becoming popular. In Bangladesh, the Code of Civil Procedure, 1908 recognises the application of tort as wrongs, but still tort law is a strange passerby with almost zero implication. Moreover, in Bangladesh, road accident cases due to negligent driving has risen to an alarming rate and regrettably people endure the most because of non application or proper application of tort law in road accident cases. Hence, there is no other option left but to start applying torts widely to control these unwanted accidents.

As courts are over burdened and struggling with a huge number of problems, practicing Common Law based equitable justice system is not an easy task for courts but it should be tried. Judges should be given proper tainting for that purpose; in addition to that, some areas of tort should be codified. The Fatal Accidents Act, 1855 should be amended with more wide lists of dependants and the process of calculating the damages should be specified.

Furthermore, there should be no bar on bringing an action against the executives because surprisingly it is true that Bangladesh being a democratic country without a Monarch, is still following the Anglo-American legal system based on the medieval Common Law theory that 'King can do no wrong' which means the Crown or State cannot be sued without its consent.

\section{CONCLUDING REMARKS}

However, despite of several legislative changes, this area of tort is still under-recognized, compared to the other areas of the tort in England. In India, the courts are welcoming tort actions and frequently emphasizing on the need for an amendment of the Fatal Accidents Act, $1855^{30}$. Recently the Supreme Court of India has boldly discarded the outdated rule of law in the case of M.C. Mehta v Union of India ${ }^{31}$, where the rule of strict liability laid down in Rylands $\mathrm{v}$ Fletcher ${ }^{32}$ has been replaced by the rule of absolute liability, in certain situations. Compared to those countries, the position of Bangladesh in this regard is quite vulnerable, though the Civil Procedure Code 1908 confreres the power to the courts to decide the matters related to personal wrongs and the wrongs of movable property as well as immovable property, but in reality, courts are deciding nothing related to such wrongs. Amendment of existing laws and codifying new laws are necessary but that is definitely not going to be enough if courts remain reluctant to decide based on the concept of justice, equity and good conscience.

\section{REFERENCES}

[1] W. Salmond; R.F. Heuston; R A Buckley, Salmond and Heuston on Law of Torts (London, Sweet \& Maxwell, 1992), 20 ${ }^{\text {th }}$ edition, pp.14,15

[2] R. K. Bangia, Law of Torts (India, Allhabad Law Agency, 2012) $15^{\text {th }}$ edition.

[3] W.V.H. Rogers, Winfield and Jolowicz on Tort (London, Sweet \& Maxwell and Thomson Reuters, 2010) $18^{\text {th }}$ edition and $1^{\text {st }}$ South Asian edition.

[4] S. Hedley, Tort (Core Text Series) (England, Oxford,2011) $7^{\text {th }}$ edition.

[5] P.S.A. Pillai, Law of Tort (Lucknow, Eastern Book Co., 2004) $9^{\text {th }}$ edition.

[6] M. Jashim Ali Chowdhury, Whither the law of torts in Bangladesh, Law Vision- 47, Journal: Critical Legal Studies Movement

[7] Tasmiah Nuhiya Ahmed http://newagebd.net/238213/tortuous-liability-road-accident-cases/, accessed on $30 / 06 / 2016$

[8] Piyush Babele, http://indiatoday.intoday.in/story/modi-government-compensation-money-road-accidentvictims/1/442934.html, accessed on 30/06/2016

[9] Amirul Islam, http://www.risingbd.com/english/jihads-death-trial-sees-no-progress/32831 date: 26th March, 2016, accessed on 30/06/2016

[10] Leonie Guguen, http://www.industriall-union.org/tazreen-victims-set-for-compensation-on-secondanniversary-of-tragedy, Date: 24 December, 2014, accessed on 12/07/2016

[11] Law Reform (Miscellaneous Provisions) Act, 1934 c. 41 (Regnal. 24_and_25_Geo_5)

[12] The Fatal Accidents Act, 1976 (c 30) (UK)

[13] The Administration of Justice Act 1982 (c 53) (UK).

[14] Damages for Bereavement (Variation of Sum) (England and Wales) Order, 2002 No. 644

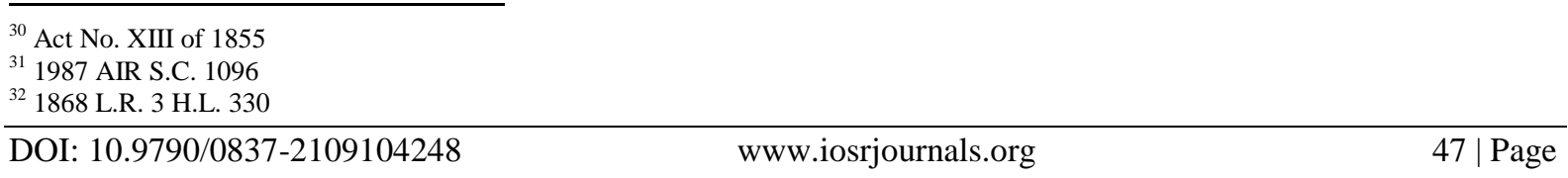


[15] The Fatal Accidents Act, 1855 (Act No. XIII of 1855) (Ind.)

[16] The Fatal Accidents Act, 1855 (Act No. XIII of 1855) (BD)

[17] Baker v Bolton (1808) 1 Camp. 493: 10 R. R. 734, 735

[18] Pym v Great Northern Railway Co. (1863) 4 B and S. 396

[19] Spittle v Bunney, (1988) 3 All ER 1031 (CA)

[20] Hicks v Chief Constable of South Yorkshire Police, (1992) 1 All ER 690 at p. 693 (CA).

[21] Taff Vale Rail Co. v Jenkins, (1913) A.C. 1. (HL)

[22] Doleman v Deakin, the Times, January 30, 1990.

[23] Budha v Union of India, A.I.R. 1981 M.P. 151

[24] P.B. Kader v Thatchamma, A.I.R. 1970 Ker. 241 at 243, per Krishna Iyer J.

[25] Dewan Hari Chand v Delhi Municipality, A.I.R. 1981 Delhi 71, at 74, 75, per V.S. Deshpande, C.J.

[26] Shashikalabai v State of Maharashtra (1999)A.I.R. S.C. 706

[27] Kumari $v$ State of Tamil Nadu (1992) AIR SC 2069

[28] Union Carbide Corporation v Union of India (Bhopal Gas Disaster case) 1988 MPLJ 540

[29] M.C. Mehta v Union of India, 1987 AIR S.C. 1096

[30] Rylands v Fletcher, (1868) L.R. 3 H.L. 330 